\title{
NATŪRALUSIS EKSPERIMENTAS KAIP SOCIALINIŲ MOKSLŲ POZITYVISTINIO TYRIMO STRATEGIJA
}

\author{
Aelita Skarbalienė \\ Klaipédos universitetas
}

\begin{abstract}
Anotacija
Nors ịvairių socialinių mokslų atstovai siekia pabrěžti ir iškelti socialinių mokslų metodologinį ir metodinį savitumą gamtos mokslų atžvilgiu, reikia pastebẻti, kad ženkliai didelè socialinių mokslų tyrimų dalis yra grindžiama pozityvistine tyrimo paradigma. Pozityvizmo tradicija tyrẻjui leidžia rinktis tam tikrus iš gamtos mokslų kilusius tyrimų metodus ir juos taikyti socialinių mokslų tyrimuose. Dèl galimybių nustatyti priežastingumą, idealiausiu empirinio tyrimo metodu laikomas eksperimentas. Vis dèlto pažymimas šio metodo sudètingas taikymas socialiniuose moksluose dèl kai kurių praktinių, politinių ir etinių aspektų. Plètojant idejjas apie tinkamą ir efektyvų eksperimentinio tyrimo metodo naudojimą socialiniuose moksluose rekomenduoja naudoti natūralujj eksperimentą. Nors pastaraisiais metais pasaulyje tyrimai, taikant natūraliojo eksperimento metodologiją ir populiarèja, vis dar stinga literatūros, kaip, kada jie gali būti taikomi, kokias socialinio gyvenimo problemas gali padèti atskleisti, kaip gali būti renkami ir analizuojami duomenys. Dẻl to metodologinès literatūros analizès pagrindu šiame straipsnyje siekiama pristatyti metodą, pateikti įžvalgas ir gaires nagrinėjamo metodo taikymui, o taip pat inspiruoti mokslinę diskusiją dèl platesnio natūraliojo eksperimento tyrimo strategijos naudojimo socialinių mokslų tyrimuose.

PAGRINDINIAI ŽODŽIAI: eksperimentas, natūralusis eksperimentas, pozityvistinè tyrimo paradigma.
\end{abstract}

\begin{abstract}
Although the representatives of different social sciences are trying to highlight and raise the methodological and methodical peculiarity of social sciences with respect to natural sciences, it should be noted that a big part of social sciences research is based on the positivist research paradigm. The positivist tradition allows a researcher to choose certain research methods that originated from natural sciences and to apply them in the research of social sciences. Regarding the possibilities to determine causality, an experiment is considered to be the best empirical research method. However, the emphasis is placed on the complicated application of this method to social sciences due to certain practical, political and ethical aspects. When developing ideas about an appropriate and effective use of the experimental research method in social sciences, the use of natural experiment is recommended. Although in recent years, the research based on the methodology of natural experiment is gaining popularity, there is still a lack of literature on how and when this methodology can be applied, what problems it can help to solve, how data can be collected and analysed. Thus, on the basis of methodological literature analysis, this article is an attempt to present natural experiment as a method for social researches, to provide guidelines and recommendations for the application of the methodology of natural experiment and to inspire scientific discussion about using the strategy of natural experiment in social sciences.

KEYWORDS: experiment, natural experiment, positivist research strategy.
\end{abstract}




\section{Pozityvizmo filosofija ir socialinių mokslų tyrimai}

Nors ịvairių socialinių mokslų atstovai siekia „pabrèžti ir iškelti socialinių mokslų metodologinị ir metodini savitumą gamtos mokslų atžvilgiu“ (Norkus, Morkevičius, Šarkutė, 2015), reikia pastebėti, kad didelè socialinių mokslų tyrimų dalis grindžiama pozityvistine tyrimo paradigma.

Pozityvistinei tyrimo paradigmai atsirasti impulsą davė XIX-XX a. vyravusi pozityvizmo filosofinè kryptis. Pozityvizmo pradininkas prancūzų filosofas $\mathrm{Au}-$ guste Comte (1798-1857) iškèlè idejąa, kad nuo iki tol vyravusio metafizinio pasaulio ir jo reiškinių aiškinimo reikia pereiti prie pozityvaus, t. y. mokslinio, žinojimo, ir teigé, kad mokslas yra vienintelis tikras ir teisingas pažinimo šaltinis (Ferré, 1988). Nurodoma, kad pozityvizmas tapo tokia filosofine mąstysena, kuri remiasi išskirtinai empiriniu pažinimu, t. y., anot E. Nekrašo, mokslinis žinojimas buvo apibrèžtas kaip vienintelè galima žinojimo forma, o pasauli pozityvizmo atstovai tyrè remdamiesi loginiu indukciniu principu ir pagrindè mintị, kad reikia kelti tokias hipotezes, kurios leistų, nors iš dalies, bet visada jas patikrinti (Nekrašas, 1979).

E. Nekrašas (2010) ypač aiškiai pateikia pozityvizmo filosofijos įtaką mokslui. Jo teigimu, ši filosofine kryptis padaré, nors ir skirtingą, bet dideli poveikị ịvairiems mokslams bei tyrimo sritims. Ši ịtaka ypač juntama socialiniuose moksluose, kurie dẻl pozityvizmo filosofijos tapo savarankiškomis disciplinomis, t. y. atsiskyrẻ nuo filosofijos. Pozityvistai rèmési metodologinio natūralizmo nuostata ir buvo įsitikinę, kad socialiniai mokslai turi būti plètojami remiantis gamtos moksluose taikomais metodais. Taigi pozityvizmas suvaidino svarbiausia vaidmeni igyvendinant empiriniais metodais besiremiančio socialinio mokslo ideją.

A. Valantiejaus (2004) teigimu, pozityvizmo siekis visą žinojimą padaryti moksliniu žinojimu būdingas ir šiomis dienomis, kai profesionaliai derinant techninius-metodinius ịgūdžius ir empirinès medžiagos kaupimą įtvirtintas pagrindžiamojo pažinimo modelis.

Pozityvizmo tradicija tyrèjui leidžia rinktis tam tikrus iš gamtos mokslų kilusius tyrimų metodus ir juos taikyti socialinių mokslų tyrimuose. H. Colin (2002), J. W. Creswell (2009), J. W. Moses, T. L. Knutsen (2012) ir kt. nuomone, dẻl galimybių nustatyti priežastingumą, idealiausiu empirinio tyrimo metodu laikomas eksperimentas.

Eksperimentiniais vadinami empiriniai tyrimai, padedantys planingai valdant (keičiant, koreguojant) proceso ar reiškinio sąlygas, patikrinti priežastinių reiškinių ryšių hipotezes. Pagrindinis eksperimentinio tyrimo bruožas - tyrëjas apgalvotai kontroliuoja ir manipuliuoja sąlygomis, kurios lemia jị dominančius ịvykius. Paprasčiau tariant, eksperimentas nustato pokyčius vienam kintamajam, kitaip dar 
vadinamam nepriklausomuoju kintamuoju, ir įvertina to pokyčio rezultatą kitam kintamajam, kuris vadinamas priklausomuoju kintamuoju (Kardelis, 2002).

\section{Eksperimentinis tyrimas socialiniuose moksluose}

Vis dèlto pažymimas šio metodo sudètingas taikymas socialiniuose moksluose dèl kai kurių praktinių, politinių ir etinių aspektų. Tai argumentuojama tuo, kad dažnai socialinių mokslų tyrimuose nẻra galimybių visiškai suvienodinti eksperimentinių ir kontrolinių grupių parametrų. Dèl to neretai atliekami tyrimai tik su iš dalies suvienodintais parametrais arba apskritai nesirūpinant jų suvienodinimu, iš anksto turint galvoje, kad parinktos tiriamuju grupès yra gana panašios. Kai grupès nevienalytės, t. y. kai jų parametrai nesuvienodinti, labai tikslių duomenų sunku tiketis. Todèl tokie tyrimai vadinami tariamais arba kvazieksperimentiniais (Kardelis, 2002). Nors dèl kvazieksperimento statuso galima diskutuoti, visgi kartais teigiama, kad toks eksperimentinio tyrimo pasirinkimas yra geresnis, negu jokio. Tačiau socialiniuose moksluose būtent tokie kvazieksperimentiniai tyrimai aptinkami dažniausiai, pavyzdžiui, A. Mažionienè, taikydama ši tyrimo metodą, tyrè savarankiško darbo, grindžiamo konstruktyvistinès teorijos idèjomis, poveikị socialinès pedagogikos studijų programų studentų vadybinių kompetencijų ugdymui(si) (2014), R. Paulauskas ir kt. - skirtingos pratybų apimties poveiki jaunujų krepšininkų pasirengimui (2015) ir pan.

\section{Filosofinių paradigmų kaitos įtaka eksperimentiniam tyrimui}

Paradigminis virsmas iš modernumo ị postmodernumą suteikè postūmị kurtis daugybei naujų kūrybinių ieškojimų sričių ir drąsiausioms mokslinio tyrimo alternatyvoms, pvz., mokslinėse diskusijose siūloma tokio metodo kaip eksperimentas nebetaikyti arba metodą adaptuoti taip, kad jis labiau atskleistų savo tyrimo objektą - kultūriškai nulemtą psichosocialinę realybę (Rutkienè, 2008). Plètodamas idèją apie eksperimentinio tyrimo metodo adaptavimą, L. Jovaiša rekomenduoja taikyti natūralujji eksperimentą, kuris atliekamas ịprastinèmis sąlygomis stebint reiškinio vystymąsi (Jovaiša, 2007). Tyrimo strategijos pasirinkimo kontekste svarbus ir Th. Dunning (2012) teiginys, kad siekiant tirti ir nagrinèti fenomenus, sukeltus kokių nors socialinių reiškinių, geriausia rinktis natūraliojo eksperimento tyrimo strategiją. Jị papildo G. D. Friedman (1980), M. R. Rosenzweig ir K. I. Wolpin (2000), J. DiNardo (2008) teiginiai, kad natūralusis eksperimentas yra viena veiksmingiausių priemonių tirti sudėtingus sveikatos, politikos mokslų, ekonomikos ir socialinių mokslų sričių socialinius reiškinius, kur svarbų vaidmenị vaidina tiriamuju santykiai ir elgsena. A. S. Gerber (2009), S. D. Hyde (2010), A. S. Gerber ir 
kt. (2011) pastebi, kad pastaraisiais metais natūralieji eksperimentai sparčiai populiarejja, ypač tiriant psichologiją, elgseną, stebint santykius.

Nors tyrimai, taikant natūraliojo eksperimento metodologiją, populiarèja, vis dar trūksta literatūros, kaip ir kada jie gali būti taikomi, kokias problemas gali padèti atskleisti, kaip gali būti renkami bei analizuojami duomenys. Taigi šio straipsnio tikslas - pateikti įžvalgų ir gairių, kaip taikyti nagrinèjamą metodą, paskatinti mokslinę diskusiją dèl platesnio natūraliojo eksperimento tyrimo strategijos taikymo įvairių socialinių mokslų tyrimuose.

\section{Eksperimentinių tyrimų ịvairovė}

Dažniausiai eksperimentu vadinamas empirinis bandymas patikrinti dèsnį arba atskleisti nežinomą reiškinị, tuo tikslu sukeliant tam tikrą tikslingą reiškini (Čiukas ir kt., 2001; Švenčianas ir kt., 2004; Žebrauskas, 2010; Rupšienė, Rutkienė, 2016, kt.).

Paprastai eksperimentiniai tyrimai skirstomi $\mathfrak{i}$ tris kategorijas: laboratorinius, lauko ir natūraliuosius eksperimentus (Kittel, Morton, 2012).

Laboratorinis yra toks eksperimentas, kai sudarant dirbtinę aplinką specialiai įrengtoje patalpoje tikrinama tiriamoji ideja griežtos požymių kontrolès sąlygomis (Stonkus, 2002). Šios kategorijos eksperimentai pasižymi tuo, kad atliekami ypatingomis, specialiai paruoštomis sąlygomis, dažnai naudojant specialius matavimo ir registravimo prietaisus. Dažniausia jie atliekami uždarose patalpose, o tiriamuju paprastai būna nedaug. Taikant ṣ̨̌ metodą tirtas mokomosios intervencijos poveikis pagyvenusiujų žmonių savarankiškumui. Taikant visas klasikinio laboratorinio eksperimento metodo procedūras eksperimentinei grupei taikyta mokomoji intervencija, t. y. kiekvienam tyrimo dalyviui sudaryta individuali mokymo programa: pratimai, priemonès plaštakos, dilbio raumenų jègai didinti, smulkiosios motorikos ir judesių koordinacijai gerinti, plaštakų mankšta, rekomenduotas apsirengimo būdas, techninès priemonès, gerinančios ligonio savarankiškumą kasdienėje veikloje. Eksperimentinis poveikis buvo taikomas stebint tyrejui, uždarose patalpose, t. y. ligoninejje (Montvydaitè, Mockienè, 2013).

Visiškai skirtinga aplinka naudojama vykdant lauko eksperimentą. Jo metu, kaip pažymi Th. Dunning (2012), B. Kittel, R. B. Morton (2012), tyrimo objektas neišskiriamas iš natūralios aplinkos, o eksperimentinè situacija nesiskiria nuo iprastų gyvenimo sąlygų. Lauko eksperimentas yra aktyviai kryptingas, tai reiškia, kad tyrejas vykdo eksperimentą ir daro poveiki jo eigai bei dalyviams. Tokio eksperimento pavyzdys gali būti A. S. Gerber ir kt. (2009) tyrimas, kai tyrejjai priešrinkiminiu laikotarpiu užsakè, kad tam tikriems atsitiktinai atrinktiems žmonėms būtų siunčiami konkrečios politinès partijos žinią skleidžiantys laikraščiai ir ste- 
bejjo jų reakcijas bei nuotaikas. Taigi eksperimentas vyko natūraliomis sąlygomis, bet tyrejjai patys organizavo ir darè poveikị tiriamiesiems.

Trečiajam eksperimentų tipui - natūraliajam eksperimentui - taip pat būdinga maksimaliai natūrali situacija, kai tiriamo objekto sistema funkcionuoja ịprastinèmis sąlygomis. Metodologinejje literatūroje (Rosenzweig, Wolpin, 2000; Dunning, 2012; Kittel, Morton, 2012, kt.) nurodoma, kad nuo lauko tyrimo natūralusis eksperimentas skiriasi tuo, kad jo metu pavieniai asmenys ar jų grupės yra veikiami tyrejjo nekontroliuojamų veiksnių ir veikia nuo tyrèjo nepriklausančiomis aplinkybėmis. Tai reiškia, kad tyrejas nedaro visiškai jokio poveikio tiriamam objektui, nesikiša ị reiškiniu, procesu kaita, o tik stebi ir laukia, kada tiriamajame procese natūraliai ịvyks pokyčiu, juos fiksuoja ir daro išvadas, pritaikomas visai populiacijai. Taikant šią tyrimo strategiją, nèra jokio dirbtinumo. Tuo šis eksperimentas skiriasi nuo klasikinių laboratorinių ir lauko eksperimentų, kur tyrejjas kruopščiai prižiūri kintamuju poveikị tiriamiesiems. Dèl šios priežasties, D. C. Mutz (2011) nuomone, natūraliojo eksperimento tyrimo strategiją geriausia rinktis atliekant didelio masto socialinị tyrimą.

\section{Eksperimentinių tyrimų kokybės reikalavimai}

R. Prakapas ir T. Butvilas (2011), apibendrindami kai kurių autorių poziciją, pateikia pagrindines eksperimentinius tyrimus apibūdinančias sąvokas. Tai objektyvumas (skaičiai ir instrumentai), vertybinis neutralumas (tyrejo atsiribojimas), anonimiškumas, paaiškinimas, priežastingumas ir koreliaciniai ryšiai, visuminis pažintinis aprépiamumas, nuo teorijos nepriklausantys faktai, struktūruota tyrimo strategija, tikslūs, tvirti ir pamatuoti duomenys, tyrimo objektas (didelès populiacijos, vidinis ir išorinis validumas, reliabilumas, reprezentatyvumas ir tendencingumas). Visas šias sąvokas galima vadinti eksperimentinių tyrimų kokybės reikalavimais.

Nepaisant pasirinkto eksperimento tipo, siekiant jo kokybės, visų pirma turi būti užtikrintas tyrimo validumas ir patikimumas. Tyrimo validumas - svarbiausias kokybinis tyrimo požymis (Stonkus, 2002), vertinamo objekto ir jam keliamų reikalavimų atitikimas (Jovaiša, 2007); tyrimo apibūdinimas, rodantis nustatytų tirtos žmonių grupès dèsningumų tikrumą ir tinkamumą visai populiacijai (Grabauskas, 2001). K. Kardelis (2002), kalbėdamas apie tyrimo metodų validumą, pažymi, kad šio termino reikšmé ne visada vienodai traktuojama. Vienu atveju validumas suprantamas kaip metodo objektyvumas, kitu - kaip patikimumas ir kt. Todèl autorius siūlo laikytis tokios šios sąvokos traktuotės: metodo validumas tai jo tinkamumas, kitaip tariant, jis užtikrina, kad atliekant tyrimą nėra sisteminės paklaidos, matuojama būtent tai, ką norima matuoti (Kardelis, 2002). A. Rutkienè 
(2008), A. Rutkienė, M. Teresevičienė (2010) nurodo, kad kai kurie autoriai pateikia nevienodus validumo veiksnius, tačiau visada jie skirstomi ị dvi pagrindines grupes: išorinio ir vidinio validumo.

Apibendrinant metodologinèje literatūroje (Kardelis, 2002; Stonkus, 2002; Morton, Williams, 2010; Hooghe, 2010; Druckman, Kam, 2011; Kittel, Morton, 2012 , kt.) pateikiamas nuomones, galima teigti, kad vidinis validumas rodo priklausomojo kintamojo pokyčius, kurie buvo nulemti jo sąveikos su nepriklausomuoju kintamuoju. Vidinio validumo sudedamosios dalys yra konstrukto (arba konstrukcinis) validumas ir priežastingumo validumas.

Konstrukto validumas rodo, kiek tam tikro konstrukto naudojimas yra pagristas ir veiksmingas. Didžiausia grèsmė konstrukto validumui yra kintamojo, neįtraukto i tyrimą, itaka tyrimo rezultatams. Priežastingumo patikimumas dar apibūdinamas ryšio pobūdžio sąvoka. Priežastingumo sąlygos atitikimas užtikrina, kad tiriamasis ryšys tikrai būtų priežasties ir padarinio ryšys.

Tuo tarpu išoriškai eksperimentas validus tada, kai skirtingoje aplinkoje ir su kitais tiriamaisiais gaunami tie patys eksperimento rezultatai, t. y. kai išvadas, padarytas tiriant vieną imtị, galima apibendrinti kitoms vietoms, kitiems žmonėms ir kitoms aplinkybėms. Taigi grèsmę išoriniam validumui gali kelti per maža tiriamųu grupè.

Išorinis eksperimento validumas skirstomas ị populiacinị ir ekologinị. Populiaciniu validumu eksperimentas pasižymi, kai jo rezultatai ir išvados gali būti pritaikomi visai populiacijai. Ekologinio patikimumo sąlyga tenkinama, kai eksperimento aplinka yra artima realaus gyvenimo situacijai. Pažymètina, kad ekologinio validumo įrodymas dažnai įrodo ir išorinio validumo buvimą.

Laboratoriniuose eksperimentuose yra didžiausia eksperimento sąlygų, elgsenos skatinimo ir elgesio sąlygų kontrolè, tad tokių tyrimų konstrukcinis patikimumas ir priežastingumo patikimumas - pagrindiniai vidinio patikimumo aspektai - yra dideli (Morton, Williams, 2010). Tačiau statistinis laboratorinių eksperimentų patikimumas socialinių mokslų tyrimuose dažnai gali būti menkas. Neretai tai lemia dèl didelių eksperimentinio tyrimo sąnaudų pasirinkta nereprezentatyvi tyrimo imtis, taip pat tai, kad laboratoriniai eksperimentai atliekami nenatūraliomis sąlygomis, todèl neaišku, kaip tiriamasis elgtųsi realioje situacijoje. Nedidelis gali būti ir laboratorinio eksperimento ekologinis patikimumas arba eksperimento realumas, t. y. aplinkos panašumo ị tikslinę aplinką lygis (Hooghe, 2010; Druckman, Kam, 2011).

\section{Natūralusis eksperimentas ir tyrimo kokybės parametrai}


Vertinant lauko ir natūraliuosius eksperimentus validumo aspektu, situacija yra atvirkštinè. Lauko ir natūraliuosiuose eksperimentuose paprastai tiriamos populiacijos ir situacijos, kurių neįmanoma ištirti laboratorijoje. Praktika rodo, kad dažnai tokių eksperimentų tiriamoji populiacija yra šalies piliečiai, kurie ịtraukiami ị didelio, kartais - nacionalinio, tyrimą, kuriame po kruopščios imties atrankos procedūros dalyvauja daug respondentų (Mutz, 2011). Pavyzdžiui, R. T. Ackermann, A. M. Holmes, C. Saha nacionaliniu mastu taikè natūraliojo eksperimento tyrimo metodologiją siekdami įvertinti Diabeto prevencijos programą (2013).

Taigi šiuo aspektu lauko tyrimas yra pranašesnis už laboratorinị. Tačiau konstrukcinis ir priežastingumo patikimumas gali būti abejotini dèl ribotų tyrèjo galimybių užtikrinti eksperimento sąlygų kontrolę.

Visgi vertinant socialinio gyvenimo daugialypiškumą, nenuspèjamumą, įvykių ir galimų pokyčių nenuspejjamumą būtent natūraliojo eksperimento tyrimo strategijos taikymas gali atskleisti realius priežastinius ir funkcinius ryšius bei nepriklausomujų kintamųu įtakos apimtis priklausomajam kintamajam, kartu atskleisdamas likusių netiriamų sąlygų įtakos mastą.

\section{Natūralusis eksperimentas, stebẻjimas ir kvazieksperimentas}

Skeptikai natūraliojo eksperimento tyrimo strategijos atžvilgiu visgi pabrèžia, kad natūralusis eksperimentas yra ne kas kita kaip stebejjimas arba tapatina ši tyrimo metodą su kvazieksperimentu. Dèl to natūraliojo eksperimento tyrimo šalininkai pateikia argumentų, kodèl šis tyrimo metodas negali būti tapatinamas nei su stebejjimu, nei su kvazieksperimentiniu tyrimu.

Th. Dunning (2012) nurodo, kad natūralieji eksperimentai dažnai priskiriami stebimiesiems tyrimams. Tačiau skirtumas tarp natūraliojo eksperimento ir neeksperimentinio stebejjimo yra tas, kad natūralusis eksperimentas naudojamas priežastinems salygoms nustatyti ir palyginti, o stebejjimo metu to nesiekiama. Be to, atlikdamas stebėjimą, tyrèjas nežino atsakymo ị keliamą klausimą ar tik miglotai ji ịsivaizduoja. Tuo tarpu eksperimente atsakymas ị keliamą klausimą pateikiamas hipotezèje, t. y. daromos prielaidos apie galimus priežastinius ryšius (Venclovienė, Jurkonis, Sujetovienè, 2014).

Yra autorių, tapatinančių natūralųji eksperimentą su kvazieksperimentu. Tačiau bene esminis dalykas, skiriantis natūralųji ir kvazieksperimentą yra tas, kad kvazieksperimente tiriamaji poveiki visada planuoja ir sukelia pats tyrèjas arba poveikis sukeliamas tyrejjo iniciatyva (Dunning, 2012), o natūraliojo eksperimento pagrindinis principas yra tas, kad tyrëjas tik stebi, vertina ir lygina pokyčius, bet jokio poveikio nedaro. 
Ivvertinus šiuos skirtumus galima teigti, kad nei stebejjimas, nei kvazieksperimentas negali būti vadinami natūraliuoju eksperimentu.

\section{Natūraliojo eksperimento tyrimo procedūros}

Pagrindinès natūraliojo eksperimento tyrimo procedūros yra tokios pat kaip ir klasikinio laboratorinio eksperimento, būtent:

(1) nustatomi visi tyrimui būtini su priklausomuoju kintamuoju susiję duomenys - pretestas;

(2) intervencijos etapas, t. y. laikotarpis, kai daromas tiriamasis poveikis. Natūraliojo ekperimento tyrimo atveju tyrejas neturi jokios įtakos intervencijai, tačiau aprašydamas tyrimą intervenciją išsamiai aprašo. Intervencijos pavyzdžiai gali būti valstybès vykdoma socialinè ar sveikatos prevencinè programa, reklama, rinkimų kampanija, naujo priimto teisès akto igyvendinimas, gamtos stichijos proveržis, ugdymo programos igyvendinimas ir pan.;

(3) intervencijai pasibaigus, atliekamas posttesto duomenų rinkimas.

\section{Duomenų rinkimas, kai taikoma natūraliojo eksperimento tyrimo strate- gija.}

Eksperimentinių tyrimų ir derinimo su kitais tyrimo metodais variacijos nėra griežtos, gali būti derinami ịvairūs duomenų rinkimo būdai, vienintelè galimų derinių riba yra akademinis kūrybingumas (Kittel, Morton, 2012). Natūraliojo eksperimento tyrimo strategiją taikantis asmuo pagal savo poreikius ir sukonstruotus tyrimo klausimus gali pats spręsti dèl duomenų rinkimo būdo (Mutz, 2011; Kittel, Morton, 2012; Dunning, 2012). Taigi pagal poreiki gali būti taikomi kiekybinių ar kokybinių duomenų rinkimo būdai ir adekvatūs jų analizès metodai.

\section{Imties sudarymo aspektai, kai taikoma natūraliojo eksperimento tyrimo strategija}

Kaip ir klasikiniame, natūraliajame eksperimente gali būti naudojamos dvi tiriamujų grupès - poveikio ir kontrolinè. Jos konstruojamos taikant ịprastas eksperimentinių grupių formavimo technikas. Tačiau dẻl tam tikrų aplinkybių gali būti naudojama tik viena grupe. Atvejų, kai dèl etinių ir (ar) praktinių aplinkybių natūralusis eksperimentas gali būti taikomas tik vienai poveikio grupei, t. y. jos nelyginant su kontroline grupe, pasitaiko neretai. Ši technika naudinga, kai norima eksperimentini tyrimą taikyti didelèje organizacijoje, o dèl jos apimties negali būti sukurta vienodų parametrų kontrolinė grupė ar kontrolinei grupei negali būti taikomas tapatus poveikis. J. O. Cooper, T. E. Heron ir W. L. Heward (2007) pagristai 
teigia, kad vienos grupès tyrimo modeliai dažniausia taikomi psichologijos, edukologijos ir elgsenos mokslų taikomosiose srityse, o tiriamoji grupé pati vaidina ir kontrolinị vaidmenị. Autorių teigimu, tokie tyrimo modeliai yra subtilesni ir geriau atskleidžia pokyčius tiriamojoje grupeje, kai tiriamosios grupès lyginimas su kontroline grupe išreiškia tik grupių statistinių vidurkių palyginimą. Vienos grupės tyrimo taikomasis pobūdis aptinkamas M. Saunders, P. Lewis, A. Thornhill (2007), D. E. Gray (2009) ir kitų tyrèjų darbuose. Autoriai mano, kad eksperimentiniai tyrimai, atliekami vienos grupès viduje, nelyginant jos su kontroline grupe, padeda geriau suvokti realias jos problemas, daryti ne universalius, o konkrečius sprendimus, tokius tyrimus vadina taikomaisiais.

Esama nuomonių, kad dviejų grupių (tiriamosios ir kontrolinès) eksperimentiniai tyrimai skirti tik intervencinio poveikio statistiniam reikšmingumui konstatuoti. Tuo tarpu tinkamai sukonstruotos imties vienos poveikio grupès eksperimentiniai tyrimai yra bene veiksmingiausia strategija, siekiant nustatyti priežastiniu veiksniu struktūrą. Tokiu atveju analizuojant statistinius duomenis rekomenduojama taikyti regresinę analizę (Huitema, 2011).

\section{Tyrimo rezultatų analizės ypatumai}

Iprastai eksperimentiniuose tyrimuose priklausomojo ir nepriklausomujų kintamujų ryšio stiprumui nustatyti taikoma koreliacinè analizè. Tačiau statistinis ryšys ne visada išreiškia ir priežastini ryšị. Todèl siekiant atskleisti priklausomojo kintamojo funkcine priklausomybę nuo kitų kintamujų, gali būti sudaromas daugialypès tiesinés regresijos modelis, kuri galima pritaikyti priklausomojo kintamojo kaitos prognozei. Funkcinė priklausomybė yra neatsitiktinių dydžių priklausomybè. Jai esant, nepriklausomų kintamųų kitimas tiksliai apibūdina priklausomojo kintamojo kitimą (Janilionis, 2011). Modeliui sudaryti gali būti pasirenkami keli nepriklausomieji kintamieji, darantys ịtaką priklausomajam kintamajam. Modelio pagrindu gali būti sudaroma regresijos lygtis, o apskaičiavus $\beta$ koeficientus, su tam tikru patikimumu galima prognozuoti priklausomojo kintamojo reikšmes, atsižvelgiant ị nepriklausomujjų kintamųjų reikšmes (Janilionis, 2011).

Kodèl regresinès analizès modelis ypač tinka natūraliojo eksperimento tyrimo duomenims nagrinèti? Atliktas tyrimas, taikant natūraliojo eksperimento tyrimo strategiją, kurio tyrimo objektas - studentų lyderystės kompetencijų pokytis studijų praktikos metu. Sudaryta regresijos lygtis „Studentų lyderystès kompetencijos (po praktikos) $=\beta_{0}+\beta_{1}{ }^{*}$ studentų lyderystės kompetencijos $+\beta_{2} *$ mentorių lyderystės kompetencijos $+\beta_{3} *$ mentoriaus atliekamos funkcijos". Remiantis natūraliojo tyrimo strategijos reikalavimais, vykdytas pretestas, t. y. išmatuotos turimos studentu lyderystės kompetencijos, vykdyta intervencija, t. y. studijų praktika, kuriai tyrèjas 
neturejo jokios įtakos, po praktikos vèl matuotos studentų lyderystès kompetencijos. Be to, ịvertintos ir visų mentorių lyderystės kompetencijos. Aprašomajame tyrime $R^{2}=0,905$ ( $\left.p=0,000\right)$, vadinasi, pasirinktos modelio dimensijos paaiškina 90,5 proc. priklausomojo kintamojo dispersijos. Šis rodiklis laikytas labai aukštu, todèl daugiau nepriklausomųjų kintamųjų neieškota (Skarbalienè, 2015).

Jeigu priklausomojo kintamojo dispersijos koeficientas būtų mažas, galima ieškoti kitų kintamųų galejusių daryti įtaką priklausomajam kintamajam intervencijos etape. Taigi galima daryti prielaidą, kad regresinès analizès taikymas ir siekis paaiškinti kuo didesnę priklausomojo kintamojo priežastinių veiksnių (faktorių) struktūrą yra ne tik būdas gauti kokybiškus tyrimo rezultatus, bet ir būdas užtikrinti eksperimentinio tyrimo išorinį validumą.

\section{Išvados}

Apibendrinant natūralusis eksperimentas yra tokia eksperimentinè tyrimo strategija, kai tyrèjas nedaro visiškai jokio poveikio tiriamam objektui, nesikiša ị reiškinių, procesų kaitą, o tik stebi, kada tiriamajame procese natūraliai ịvyks pokyčių, juos fiksuoja, vertina, lygina ir daro išvadas. Jis pritaikomas visai populiacijai. Kadangi tarpdisciplininių mokslinių tyrimų vis daugejja, turimos žinios keliamos ị naujus kontekstus, reikia tyrimų metodų, kurie leistų kitaip parodyti esamą situaciją atskleidžiant socialinę realybę. Natūraliojo eksperimento tyrimo strategija tokiu atveju ypač tinka vykdant didelio masto socialinių, sveikatos, politikos, ekonomikos mokslų tyrimus, kai tiriami nuo tyrèjo nepriklausomi reiškiniai ir jų priežastys, atsiradusios dažniausia kaip visuomeninio gyvenimo pasekmè.

Natūralusis eksperimentas atliekamas nacionaliniu mastu vienos grupès viduje padeda geriau suvokti realias jos problemas, daryti konkrečius sprendimus ir gali būti vadinamas taikomиoju tyrimu. Tikètina, kad tokiam tyrimui keliami metodologiniai reikalavimai ir tyrejjo nesikišimas sudaro galimybes tyrejui nustatyti realius priežasties ir pasekmės funkcinius ryšius.

\section{Literatūra}

Ackerman, R. T., Holmes, A. M., Saha, C. (2013). Designing a natural experiment to evaluate a national health care-community partnership to prevent type 2 diabetes. Preventing Chronical Disease, Vol. 10, p. 120-149.

Bilevičienè, T., Jonušauskas, S. (2011). Statistinių metodu taikymas rinkos tyrimuose. Vilnius: Mykolo Romerio universiteto leidybos centras.

Blunch, N. J. (2008). Introduction to structural equation modeling using SPSS and AMOS. Los Angeles: Sage Publications.

Burns, R. A., Burns, R. B. (2008). Business researh method and statistics using SPSS. London: Sage Publications.

Colin, H. (2002). Political Analysis: A Critical Introduction. Basingstoke: Palgrave.

Connolly, P. (2006). Quantitative data analysis in education: a critical introduction using SPSS. London, New York: Routledge. 


\section{NATŪRALUSIS EKSPERIMENTAS KAIP SOCIALINIŲ MOKSLŲ POZITYVISTINIO...}

Cooper, J. O., Heron, T. E., Heward, W. L. (2007). Applied Behavior Analysis. 2nd ed. Englewood Cliffs, NJ: Prentice Hall.

Creswell, J. W. (2009). Research Design. Qualitative, Quantitative and Mixed Methods Approaches. Los Angeles: Sage.

Čekanavičius, V., Murauskas, G. (2004). Statistika ir jos taikymai II. Vilnius.

Čekanavičius, V., Murauskas, G. (2004). Statistika ir jos taikymai II. Vilnius: TEV.

Čiukas, R., Katunskis, J., Kaulakienė, A. ir kt. (2001). Aiškinamasis tekstilès terminu žodynas: su vokiečiu, anglu, prancūzu ir rusu kalbu atitikmenimis. Kaunas: Technologija.

DiNardo, J. (2008). Natural experiments and quasi-natural experiments. The New Palgrave Dictionary of Economics. Second ed. Palgrave Macmillan.

Doane, D., Seward, L. W. (2011). Applied statistics in business and economics. New York: McGraw-Hill.

Druckman, J. N., Kam, C. D. (2011). Students as Experimental Particiants: Defense of the 'Narrow Data Base'. In: J. N. Druckman, D. P. Green, J. H. Kuklinski, A. Lupia (eds.). Handbook of Experimental Political Science. New York: Cambridge University Press.

Duning, Th. (2012). Natural experiments in the Social Sciences: a Design - Based Approach. New York: Cambridge University Press.

Ferré, F. (1988). Comte Auguste. Introduction to Positive Philosophy. Cambridge: Hackett Publishing Company.

Friedman, G. D. (1980). Primer of Epidemiology. 2nd ed. New York: McGraw-Hill.

Gerber, A. S., Karlan, D. S., and Bergan, D. (2009). Does the media matter? A field experiment measuring the effect of newspapers on voting behavior and political opinions. American Economic Journal: Applied Economics, p. 35-52.

Gerber, A. S., Kessler, D. P., Meredith, M. (2011). The Persuasive Effects of Direct Mail: A Regression Discontinuity Based Approach. Journal of Politics, No. 73, p. 140-155.

Grabauskas, V. (2001). Pagrindinés epidemiologijos savokos. Mokomasis žodynas. Kaunas: KMU Spaudos ir leidybos centro leidykla.

Gray, D. E. (2009). Doing Research in the Real Word. London: Sage Publications.

Hyde, S. D. (2010). Experimenting in Democracy Promotion: International Observers and the 2004 Presidential Elections in Indonesia. Perspectives on Politics, Vol. 8, No. 2, p. 511-527.

Hooghe, L. H. (2010). The Rise of Regional Authority. A Comparative Study of 42 Democracies. Routledge.

Huitema, B. E. (2011). The Analysis of Covariance and Alternatives Statistical Methods for Experiments, QuasiExperiments, and Single-Case Studies. Hoboken, New Jersey: John Wiley \& Sons, Inc.

Janilionis, V. (2011). Daugialypès regresinès analizes taikymas socialiniuose tyrimuose. ES struktūriniu fondu lëšomis igyvendinto projekto „Lietuvos HSM duomenu archyvo (LiDA) plètra" mokomoji medžiaga. Kaunas: Kauno technologijos universitetas.

Jovaiša, L. (2007). Enciklopedinis edukologijos žodynas. Vilnius: Gimtasis žodis.

Kardelis, K. (2002). Moksliniu tyrimu metodologija ir metodai (edukologija ir kiti socialiniai mokslai). Vadovèlis. 2-asis pataisytas leidimas. Kaunas: Judex.

Kittel, B., Morton, R. B. (2012). Introduction: Experimental Political Science in Perspective. In: B. Kittel, W. J. Luhan, R. B. Morton. Experimental Political Science. Principles and Practices. Hampshire: Palgrave Macmillan.

Mažioniené, A. (2014). Savarankiško darbo įtaka socialinès pedagogikos studijų programų studentų vadybinių kompetencijų ugdymui/si. Tiltai, Nr. 1, p. 137-149.

Montvydaite, M., Mockienė, V. (2013). Mokomosios intervencijos poveikis pagyvenusiųžmonių savarankiškumui. Visuomenès sveikata, priedas Nr. 1, p. 56-62.

Morton, R., Williams, K., eds. (2010). Experimental Political Science and the Study of Causality: From Nature to the Lab. Cambridge University Press.

Moses, J. W., Knutsen, T. L. (2012). Ways of Knowing: Competing Methodologies in Social and Political Research. 2nd ed. New York: Palgrave.

Mutz, D. C. (2011). Population-Based Survey Experiments. Princeton: Princeton University Press.

Norkus, Z., Morkevičius, V., Šarkutè, L. (2015). Lyginamieji tyrimai su Tosmana ir FS/QCA. Pavyzdinis metodologinis mokomasis studiju paketas. Prieiga internete http://www.lidata.eu/index.php? file=files/ mokymai /qca/qca.html\&course_file=qca_ii_6.html [žiūrèta 2016-04-27].

Pallant, J. (2007). SPSS Survival Manual: A Step by Step Guide to Data Analysis using SPSS for Windows. 3rd ed. Open University Press. 
Paulauskas, R. ir kt. (2015). Skirtingos pratybų apimties poveikis jaunujų krepšininkų parengtumui. Sporto mokslas, Nr. 2(80), p. 35-39.

Prakapas, R., Butvilas, T. (2011). Mokslinio tiriamojo darbo logografija studijoms. Vilnius: Mykolo Romerio universitetas.

Rosenzweig, M. R., Wolpin, K. I. (2000). Natural „Natural Experiments“ in Economics. Journal of Economic Literature, No. 38(4), p. 827-874.

Rupšienė, L., Rutkienė, A. (2016). Edukacinis eksperimentas. Klaipèda: Klaipėdos universiteto leidykla.

Rutkiené, A. (2008). Edukologinio eksperimento tinkamumo ir patikimumo planavimas. Daktaro disertacija. Vytauto Didžiojo universitetas.

Rutkienė, A., Teresevičienė, M. (2010). Eksperimento planavimo gerinimas - svarbi edukologinių tyrimų kokybès prielaida. Aukštojo mokslo kokybè, Nr. 7, p. 88-107.

Saunders, M., Lewis, P., Thornhill, A., (2007). Research Methods for Business Students. 4th ed. Prentice Hall.

Skarbalienè, A. (2015). Mokytoju mentoriu lyderystès kompetencijos kaip studentu lyderystès kompetenciju ugdymo veiksnys. Daktaro disertacija. Klaipédos universitetas.

Stonkus, S. (rengejjas) (2002). Sporto terminu žodynas, T. 1. 2-asis patais. ir papild. leid. Aiškinamasis žodynas. Angliški, vokiški, rusiški terminų atitikmenys. Būtiniausios žinios. Kaunas: LKKA.

Švenčianas, P., Adomavičius, A., Buinevičius, K., kt. (2004). Aiškinamasis šiluminés ir branduolinès technikos terminu žodynas. Kaunas: Technologija.

Venclovienė, J., Jurkonis, N., Sujetovienė, G. (2014). Moksliniu tyrimu metodologija. Prieiga internete: $<$ http:// aplinkotyra.vdu.lt/material/moduliai/mt_metodologija/skaidres/s5\%20tema.pdf.> [žiūrèta 2014-06-04].

Žebrauskas, S., kt. (2010). Aiškinamasis elektrotechnikos terminu žodynas: lietuviu k., vokiečiu k., anglu k., prancūzu k., rusu $k$. Kaunas: Technologija.

\section{A NATURAL EXPERIMENT AS A POSITIVIST RESEARCH STRATEGY}

\section{Aelita Skarbaliené}

\section{Summary}

Although the representatives of different social sciences are trying to highlight and raise the methodological and methodical peculiarity of social sciences with respect to natural sciences (Norkus, Morkevičius, Šarkute, 2015), it should be noted that a big part of social sciences research is based on the positivist research paradigm. The positivist tradition allows a researcher to choose certain research methods that originated from natural sciences and to apply them in the research of social sciences. In the view of H. Colin (2002), J. W. Creswell (2009), J. W. Moses, T. L. Knutsen (2012) etc., regarding the possibilities to determine causality, an experiment is considered to be the best empirical research method. However, the emphasis is placed on the complicated application of this method to social sciences due to certain practical, political and ethical aspects. When developing ideas about an appropriate and effective use of the experimental research method in social sciences, the use of natural experiment is recommended. Although in recent years, the research based on the methodology of natural experiment is gaining popularity, there is still a lack of literature on how and when this methodology can be applied, 
what problems it can help to solve, how data can be collected and analysed. Thus, on the basis of methodological literature analysis, this article is an attempt to provide guidelines and recommendations for the application of the methodology of natural experiment in the researches of different social, health, political and economic sciences and inspire the scientific discussion about application of this research strategy.

The main insights:

1. A natural experiment is an experimental research strategy when a researcher does not make any impact on the researched object, does not interfere into the change of the phenomena and processes, but simply observes and waits for the natural changes to take place in the researched process, records changes and draws conclusions that can be applied to the population.

2. The research strategy of a natural experiment is especially useful when carrying out the research of social, health, political and economic phenomena at the national level, when the causes which do not depend on the researcher and which usually occur as a result of public life are investigated.

3. Due to the conditions of large sample and natural environment, a natural experiment is characterised by high external validity.

4. The use of regression analysis and an attempt to explain the as high as possible structure of the causative factors of a dependent variable are not only a way to get high-quality research results, but also a way to ensure the internal validity of experimental research.

5. A natural experiment carried out at the national level within one group sample facilitates a better understanding of real problems, specific solutions, and can be called as an applied research. Special methodological requirements and the fact that a researcher does not make any impact enable the researcher to identify real functional relations between the cause and the effect. 
